\title{
Effect of carboxymethyl cellulose coating enriched with clove oil on postharvest quality of 'Xinyu' mandarin oranges
}

\author{
Chu-Ying Chen ${ }^{\star}$, Jia-Peng Zheng, Chun-Peng Wan, Ming Chen and Jin-Yin Chen ${ }^{\star \star}$
}

Jiangxi Key Laboratory for Postharvest Technology and Nondestructive Testing of Fruits \& Vegetables, College of Agriculture, Jiangxi Agricultural University, Nanchang 330045, PR China

Received 12 September 2016 - Accepted 4 March 2016

\begin{abstract}
Introduction. Attempts to exploit natural preservatives to control postharvest diseases as an alternative technology to synthetic fungicides in citrus fruit have been drawing much attention. Materials and methods. The combined effects of carboxymethyl cellulose (CMC) coating and/or clove oil on the qualitative properties of cold-stored 'Xinyu' mandarin oranges stored at $5{ }^{\circ} \mathrm{C}$ for 120 days were investigated. Results and discussion. The results showed that the addition of clove oil as an antifungal component to the CMC coating had a good effect on the inhibitory growth of fungal decay, and the coating treatments significantly decreased the decay rate and weight loss, as well as the maleic dialdehyde (MDA) concentration compared with control samples. The clove oil-carboxymethyl cellulose (CO-CMC) coating significantly maintained commercial quality and inhibited respiration. Meanwhile, the results showed that the activities of superoxide dismutase (SOD), catalase (CAT), polyphenol oxidase (PPO) and phenylalanine ammonia lyase (PAL) in fruit treated with CO-CMC coating were higher than in those treated with CMC coating and control samples. Conclusion. The CO-CMC coating has good potential for application as an alternative to synthetic fungicides for improving postharvest quality and prolonging the shelf life of 'Xinyu' mandarin oranges during cold storage.
\end{abstract}

Keywords: China / mandarin / Citrus reticulata / CMC / postharvest quality / integrated disease management / clove oil / enzyme activity / shelf life

\begin{abstract}
Résumé - Effet de l'enrobage au carboxyméthyl de cellulose enrichi avec de l'huile de clou de girofle sur la qualité des mandarines 'Xinyu' après récolte. Introduction. Les tentatives visant à exploiter les conservateurs naturels ont beaucoup attiré l'attention dans la perspective de contrôler les maladies sur agrumes après récolte comme technologie alternative aux fongicides de synthèse. Matériel et méthodes. Les effets combinés du carboxyméthyl de cellulose (CMC) en enrobage avec ou sans huile de clou de girofle ont été étudiés sur les propriétés qualitatives des mandarines 'Xinyu' stockées à $5{ }^{\circ} \mathrm{C}$ pendant 120 jours. Résultats et discussion. L'ajout d'huile de clou de girofle comme composant antifongique dans l'enrobage au CMC a eu un effet positif sur l'inhibition de croissance de la pourriture fongique, et les traitements d'enrobage ont diminué de manière significative le taux de décroissance, la perte de poids, ainsi que la teneur en dialdéhyde maléique (MDA) par rapport aux échantillons témoins. La combinaison huile de clou de girofle-CMC a sensiblement maintenu la qualité commerciale et inhibé la respiration. Dans le même temps, les activités enzymatiques de la superoxyde dismutase (SOD), de la catalase (CAT), de la polyphénol oxydase (PPO) et de la phénylalanine ammonialyase (PAL) étaient plus élevées au sein des fruits enrobés (huile de clou de girofle-CMC) que dans les échantillons enrobés au CMC seul ou dans ceux du témoin. Conclusion. L'enrobage huile de clou de girofle-CMC présente un fort potentiel d'utilisation comme alternative aux fongicides de synthèse pour améliorer la qualité post-récolte et prolonger la durée de conservation des mandarines 'Xinyu' pendant le stockage au froid.
\end{abstract}

Mots clés : Chine / mandarine / Citrus reticulata / CMC / qualité post-récolte / gestion intégrée des maladies / activité enzymatique / durée de conservation

\section{Introduction}

'Xinyu' mandarin oranges (Citrus reticulata Blanco cv. Tangerine), which are well known for their uniform color,

^ Chu-Ying Chen and Jia-Peng Zheng contributed equally to this work and should be considered co-first authors.

$\star \star$ Corresponding author: jinyinchen@126.com consistent size, delicate flesh, rich juice, less dregs and delicious taste, are among the economically important fruits endemic to Xinyu City in China [1]. This is one of the main citrus cultivars in Jiangxi province, and is popularly known as 'Nanfeng' mandarin. However, these citrus fruits ripen early in November; the rapid postharvest physiological changes account for a short harvest period, and pose great challenges for 
both picking and marketing [2]. Quality loss, including the losses of nutrient substance, water and disease resistance, are the most important characteristics indicating the deterioration of 'Xinyu' mandarin orange; these changes directly affect the quality of the fruit, as well as their storability, transportability and marketability.

At present, citrus fruits destined for long-term storage generally rely mainly on the use of chemical fungicides, especially imazalil, prochloraz, thiabendazole, fludioxonil, pyrimethanil or different mixtures of these compounds. However, their use is increasingly restricted because of concerns regarding the potentially harmful impact on human health, environmental pollution, and the development of fungicide-resistant pathogens. Therefore, safer and more eco-friendly alternative treatments of citrus postharvest diseases have become an urgent need for controlling postharvest decay of citrus fruit.

Clove oil, distillated from the flower buds of the clove ( $\mathrm{Eu}$ genia caryophllata Thunb.), is widely used and well known for its antioxidant, antimicrobial, antifungal and antiviral activity [3], and has been listed as a "generally regarded as safe" substance by the United States Food and Drug Administration (FDA) when administered at dosages not exceeding 1,500 ppm in all food categories [4]. The main chemical compositions of clove oil are eugenol (76.8\%), $\beta$-caryophyllene (17.4\%), $\alpha$ humulene $(2.1 \%)$, and eugenyl acetate $(1.2 \%)$ [3], which are natural and harmless for people and the environment. Clove oil and its active substances have been tested for inhibitory activity against Penicillium italicum [5], Penicillium digitatum [6], Laetiporus sulphureus [7], Aeromonas hydrophila and Enterococcus faecalis [8].

Carboxymethyl cellulose (CMC) from sugar beet pulp cellulose is the most important water-soluble cellulose derivative that has received a great deal of attention, with several examples of applications in many fruits and vegetables. A novel edible coating formulation based on CMC and other coalescing agents has, for instance, been applied to strawberries [9], jujubes [10], pears and peaches [11], and many other fruits. Although polysaccharide film and/or essential oil were applied to several fruits and vegetables, no data are available of CMC coating enriched with clove oil and their effect on the quality of 'Xinyu' mandarin orange, to the best of our knowledge. The objectives of this study were to investigate the effects of CMC enriched with clove oil on quality properties and pertinent enzyme activities of 'Xinyu' mandarin oranges during storage at $5{ }^{\circ} \mathrm{C}$ for 120 days.

\section{Materials and methods}

\subsection{Fruit material}

The 'Xinyu' mandarin oranges (Citrus reticulata Blanco cv. Tangerine) used throughout this study were harvested from a local orchard located in the Yushui district of Xinyu City (Jiangxi Province, China). The fruit was picked on the basis of consistent size and uniform color, and without bruises or disease. Then, the fruit was immediately carried back to the Jiangxi Key Laboratory for Postharvest Technology and Nondestructive Testing of Fruits and Vegetables within $2 \mathrm{~h}$.

\subsection{Evaluation of antifungal activity}

\subsubsection{Plant pathogens}

The Penicillium italicum, Penicillium digitatum, Geotrichum candidum var. citri-aurantii and Alternaria citri used in this investigation were provided by the Jiangxi Key Laboratory for Postharvest Technology and Nondestructive Testing of Fruits and Vegetables (Nanchang, China). All the test strains were maintained on potato dextrose agar (PDA) plates at $4{ }^{\circ} \mathrm{C}$ to maintain their pathogenicity. The concentration of the Penicillium spore suspensions $\left(10^{5}\right.$ spore $\left.\mathrm{mL}^{-1}\right)$ was determined with the aid of a hemocytometer.

\subsubsection{In vitro antifungal activity assay of clove oil}

The antifungal activity assay of clove oil was determined by using a modified agar-well diffusion assay method with slight modifications. Briefly, clove oil was dissolved in sterile distilled water containing $0.1 \%(\mathrm{v} / \mathrm{v})$ Tween 80 , and then added to the sterile culture medium (PDA) at the specified concentrations selected based on the preliminary experiments done in the laboratory. Following thorough mixing, the media were poured into Petri dishes $(90 \mathrm{~mm})$. Thereafter, the agar-mycelial plugs (6 $\mathrm{mm}$ diameter) infected with fungi were placed in the center of each PDA plate, and then the Petri dishes were sealed with parafilm and incubated at $25^{\circ} \mathrm{C}$ in the dark. Colony growth diameters were measured until the fungal hyphae reached the edge of the control plate without any additives. The experiments were carried out with three replicates per treatment and 5 plates were used in each replicate. The minimum inhibitory concentration (MIC) was established as the lowest concentration that resulted in no visible growth of the tested fungi incubated at $25^{\circ} \mathrm{C}$ for $48 \mathrm{~h}$ [12]. The antifungal activity of clove oil was expressed as percentage inhibition of mycelial growth $(I M G)$ using the following formula:

$$
\operatorname{IMG}(\%)=\frac{(d c-d t) \times 100}{(d c-6)}
$$

where $d c$ and $d t$ were the averages from three replicates of mycelium diameters $(\mathrm{mm})$ of the control and the treatment, respectively.

\subsubsection{In vivo antifungal activity assay of clove oil}

The antifungal assay of clove oil against $P$. italicum in vivo on citrus fruit was evaluated according to the modified method of Xu et al. [13] (fruit pathology test). The selected fruit of the same size and color, without any injuries or infections, were dipped in $1 \%$ sodium hypochlorite solution for $2 \mathrm{~min}$, rinsed with sterile water, and air-dried before wounding.

Fruit was wounded in the equatorial region with a sterile puncher to generate a uniform wound (4 mm diameter, $2 \mathrm{~mm}$ deep) and then divided randomly into six groups and placed in containers $(35 \mathrm{~cm} \times 26 \mathrm{~cm}$ white plastic boxes). A volume of $15 \mu \mathrm{L}$ clove oil at $0.5,1.0,2.0,4.0$ and $8.0 \mathrm{~mL} \mathrm{~L}^{-1}$, along with sterile distilled water as the control, were pipetted 
into individual wounds. After $30 \mathrm{~min}, 15 \mu \mathrm{L}$ spore suspension of $P$. italicum $\left(5 \times 10^{4}\right.$ spore $\left.\mathrm{mL}^{-1}\right)$ was inoculated into each wound. The lesion diameters of decayed fruits were recorded after 7 days of incubation at $25^{\circ} \mathrm{C}$, with the formula:

$$
\begin{aligned}
& \text { Inhibition }(\%)= \\
& \frac{(\text { lesions diameters of control }- \text { lesions diameters of treatment }) \times 100}{\text { lesions diameters of control }}
\end{aligned}
$$

Ten fruits were used in a treatment and each treatment was carried out with three replicates.

\subsection{Preparation of coating and treatment}

CMC solution $(1.0 \%$, w/v) was prepared by dissolving $10.0 \mathrm{~g}$ CMC powder in $1,000 \mathrm{~mL}$ distilled water, containing $0.07 \%$ citric acid, $1.0 \%$ sucrose esters and $1.0 \%$ calcium propionate, with agitation for $8 \mathrm{~h}$. All the film-forming aids were food-grade. Five $\mathrm{mL}$ clove oil (Jian Shenada Perfume Ltd., Jiangxi, China) was added to the coating, with agitation for $1 \mathrm{~h}$.

The selected fruits were washed with tap water and airdried at room temperature $\left(25 \pm 1{ }^{\circ} \mathrm{C}\right)$, then coated by dipping in the CMC coating and/or clove oil for $2 \mathrm{~min}$, while the control group was washed and left without coating. After drying, the coated as well as control fruits were film-packaged individually, and then pre-cooled $\left(10^{\circ} \mathrm{C}, 12 \mathrm{~h}\right)$. Finally, all fruits were stored at $5{ }^{\circ} \mathrm{C}$ and $90 \% \mathrm{RH}$.

\subsection{Measurement of weight loss and decay rate}

A total of 150 fruits were divided randomly into three groups to measure the weight loss and decay rate. Ten fruits per treatment were used to measure weight loss, and another 40 fruits were used to measure the decay $\%$, respectively. The weight loss of the samples was measured during storage every 20 days and compared with the initial weight. The decay $\%$ was expressed by the percentage of fruits indicating fungal disease.

\subsection{Determination of fruit quality}

The total soluble solid (TSS) concentration in the pulp was assayed by a RA-250 WE digital Brix meter (KYOTO, Tokyo, Japan) and the value was expressed in ${ }^{\circ}$ Brix. The titratable acidity (TA) in the pulp $(5.0 \mathrm{~g})$ was titrated to $\mathrm{pH} 8.1$ with $0.1 \mathrm{~N} \mathrm{NaOH}$ and expressed as a percentage of citric acid. For the analysis of vitamin C, pulp tissue ( $4.0 \mathrm{~g}$ ) was well homogenized with $20 \mathrm{~mL}$ of $2 \%(\mathrm{w} / \mathrm{v})$ oxalic acid and centrifuged at $12,000 \mathrm{~g}$ at $4{ }^{\circ} \mathrm{C}$ for $10 \mathrm{~min}$. The vitamin $\mathrm{C}$ (VC) concentration in the supernatant was titrated with a standard 2,6dichlorophenolindophenol and the results were expressed as $\mathrm{mg}$ ascorbic acid per $100 \mathrm{~g}$ fresh fruit pulp.

\subsection{Measurement of MDA concentration and respiration rate}

Peel tissue $(2.0 \mathrm{~g})$ from 10 fruits in each treatment was homogenized in $10 \mathrm{~mL}$ of $50 \mathrm{mM}$ phosphate (PBS) buffer at $\mathrm{pH} 7.8$ and then centrifuged at $12,000 \mathrm{~g}$ for $20 \mathrm{~min}$. The maleic dialdehyde (MDA) concentration was measured according to the method of Hodges et al., with slight modifications [14]. The supernatant was collected and $2.5 \mathrm{~mL}$ was mixed with $2.5 \mathrm{~mL}$ of $0.5 \%$ thiobarbituric acid. The mixture was heated to $100{ }^{\circ} \mathrm{C}$ for $30 \mathrm{~min}$, quickly cooled and centrifuged at $6,000 \mathrm{~g}$ for $10 \mathrm{~min}$. The supernatant was collected to test absorbance at 450,532 and $600 \mathrm{~nm}$. The $M D A$ concentration $\left(\mathrm{mmol} \mathrm{g}^{-1} \mathrm{FW}\right)$ was calculated according to the formula:

$$
M D A=\left[6.452 \times\left(A_{532}-A_{600}\right)-0.559 \times A_{450}\right]
$$

The measurement of the $\mathrm{CO}_{2}$ concentration was made on 10 fruits from each treatment, which were placed in an airtight Plexiglas jar with a metal probe in the headspace for $2 \mathrm{~h}$ at $25^{\circ} \mathrm{C}$ prior to gas sampling. The $\mathrm{CO}_{2}$ concentration was recorded by a GHX-3051H infrared $\mathrm{CO}_{2}$ fruit and vegetable breathing apparatus (Jingmi Scientific LLC., Shanghai, China). The respiration rate was expressed as $\mathrm{mg} \mathrm{CO}_{2} \mathrm{~kg}^{-1} \mathrm{~h}^{-1}$ fresh weight (FW) and calculated by using the following equation:

$$
\text { Respiration rate }=\frac{\Delta \mathrm{CO}_{2}}{100} \cdot V_{\text {headspace }} \cdot \frac{1000}{m} \cdot \frac{60}{t}
$$

where $m$ is the mass of Xinyu mandarin oranges $(\mathrm{g}), V_{\text {headspace }}$ is the empty volume of the $\mathrm{jar}(\mathrm{mL}), \Delta \mathrm{CO}_{2}$ is the difference between the initial and final concentration of $\mathrm{CO}_{2}$, and $t$ is the recording time (min).

\subsection{Measurement of enzyme activity}

All steps in the proposal for crude enzymes were carried out at $4{ }^{\circ} \mathrm{C}$. Peel samples $(2 \mathrm{~g})$ from 10 fruits in each treatment were homogenized in $25 \mathrm{~mL}$ of ice-cold $50 \mathrm{mM}$ phosphate buffer at $\mathrm{pH} 7.8$, containing $0.5 \mathrm{mM}$ ascorbic acid, $1 \mathrm{mM}$ ethylenediaminetetraacetic acid (EDTA) and 2\% polyvinylpyrrolidone (PVP, $\mathrm{m} / \mathrm{V}$ ) and centrifuged at $12,000 \mathrm{~g}$ for $30 \mathrm{~min}$ at $4{ }^{\circ} \mathrm{C}$. For polyphenol oxidase (PPO), a 1-g peel sample was extracted with $100 \mathrm{mM}$ ice-cold sodium acetate buffer at $\mathrm{pH} 5.5$, containing $1 \mathrm{mM}$ polyethylene glycol (PEG), $4 \% \operatorname{PVP}(\mathrm{m} / \mathrm{V})$ and $1 \%$ Triton X-100 (m/V). To measure phenylalanine ammonia lyase (PAL) activity, 2-g peel samples were ground with $50 \mathrm{mM}$ ice-cold Tris- $\mathrm{HCl}$ buffer at $\mathrm{pH} 8.8$, containing $15 \mathrm{mM} \beta$-mercaptoethanol, $5 \mathrm{mM}$ EDTA, $5 \mathrm{mM}$ ascorbic acid, $1 \mathrm{mM}$ phenylmethanesulfonyl fluoride (PMSF) and $4 \%$ PVP $(\mathrm{m} / \mathrm{V})$.

Total SOD activity was determined by using a "SOD Detection Kit", following the manufacturer's instructions (NJBI, Nanjing, China). The absorbance was monitored at $550 \mathrm{~nm}$ (Shimadzu UV-1800, Japan). One unit of SOD is the amount of extracts that gives $50 \%$ inhibition of reduction of xanthine. CAT activity determination was performed according to the method of Havir and Rober, with slight modifications [15]. 
Table I. In vitro effect of clove oil on inhibition of mycelial growth (IMG, in \%) of Penicillium italicum, Penicillium digitatum, Geotrichum citri-aurantii var. citri-aurantii and Alternaria citri. Each value represents the mean \pm standard error $(n=5)$.

\begin{tabular}{|c|c|c|c|c|c|c|c|}
\hline \multirow{2}{*}{ Pathogens } & \multicolumn{6}{|c|}{ IMG $(\%)$ at various concentrations $\left(\mu \mathrm{g} \mathrm{L}^{-1}\right)^{\mathrm{y}}$} & \multirow[t]{2}{*}{$\begin{array}{c}\mathrm{MIC}^{\mathrm{z}} \\
\left(\mu \mathrm{g} \mathrm{L}^{-1}\right)\end{array}$} \\
\hline & 100 & 200 & 500 & 1000 & 2000 & 3000 & \\
\hline P. italicum & $21.6 \pm 1.57^{j}$ & $50.2 \pm 0.95^{\mathrm{g}}$ & $83.1 \pm 2.16^{\mathrm{d}}$ & $100^{\mathrm{a}}$ & $100^{\mathrm{a}}$ & $100^{\mathrm{a}}$ & 200 \\
\hline P. digitatum & $4.0 \pm 0.55^{1}$ & $35.5 \pm 1.61^{\mathrm{h}}$ & $64.8 \pm 1.91^{\mathrm{f}}$ & $96.3 \pm 2.49^{b}$ & $100^{\mathrm{a}}$ & $100^{\mathrm{a}}$ & 500 \\
\hline G. citri-aurantii var. citri-aurantii & $36.7 \pm 1.80^{h}$ & $49.4 \pm 1.44^{\mathrm{g}}$ & $73.3 \pm 0.89^{\mathrm{e}}$ & $91.6 \pm 1.92^{\mathrm{c}}$ & $100^{\mathrm{a}}$ & $100^{\mathrm{a}}$ & 500 \\
\hline A. citri & $11.3 \pm 1.69^{\mathrm{k}}$ & $28.7 \pm 1.35^{\mathrm{i}}$ & $48.9 \pm 1.12^{\mathrm{g}}$ & $67.4 \pm 1.82^{f}$ & $84.5 \pm 1.88^{\mathrm{d}}$ & $100^{\mathrm{a}}$ & 1,000 \\
\hline
\end{tabular}

${ }^{y}$ Means followed by different lowercase letters are significantly different according to Duncan's new multiple range test $(P<0.05)$.

${ }^{\mathrm{z}}$ Minimum inhibitory concentrations.

CAT activity was expressed as $\mathrm{U}_{\mu} \mathrm{L}^{-1}$, where one unit was 0.01 absorbance change $\mathrm{min}^{-1}$ at $240 \mathrm{~nm}$. PPO activity was based on the determination of catechol oxidation at $420 \mathrm{~nm}$. One unit of PPO activity was defined as the amount of enzyme extract causing absorbance increase per minute under the conditions of the assay. PAL activity was determined according to the method described by Ballester [16]. One unit was defined as the amount of $1 \mu \mathrm{g}$ trans-cinnamic acid released $\mathrm{h}^{-1}$.

\subsection{Statistical analysis}

The experimental data were analyzed as a completely randomized design with three replicates. All statistical analysis was performed using Duncan's multiple range test (SPSS version 17.0) and the least significant difference (LSD) at $P=0.05$.

\section{Results and discussion}

\subsection{In vitro antifungal activity}

The effect of clove oil on mycelial growth of P. italicum, $P$. digitatum, G. candidum var. citri-aurantii and $A$. citri was observed on PDA plates. As shown in table $I$, the growth of $P$. italicum was completely inhibited when the concentration of clove oil reached $1,000 \mu \mathrm{L} \mathrm{L}^{-1}(\mathrm{v} / \mathrm{v})$ and the value of MIC was $200 \mu \mathrm{L} \mathrm{L}^{-1}$. With $1,000 \mu \mathrm{L} \mathrm{L}^{-1}$ clove oil, the IMG and MIC of P. digitatum and G.candidum var. citri-aurantii were $96.3 \%$ and $91.6 \%$, and $500 \mu \mathrm{L} \mathrm{L}^{-1}$, respectively. These results indicated that there was a significantly positive correlation between the concentration of clove oil applied and the IMG of four kinds of postharvest fungal decay in citrus fruit.

Attempts to exploit natural preservatives to control postharvest diseases as an alternative technology to synthetic fungicides in citrus fruit have been drawing much attention [26]. Hence, the presence of antifungal compounds in plant essential oils of extracts has been recognized for a long time, and the inhibitory effects of plant essential oils or crude extracts and their active ingredients against pathogenic fungi have been demonstrated in numerous studies. Our previous work has already verified that clove oil has strong antifungal activity against the main fungal diseases in citrus fruit, such as $P$. italicum, $P$. digitatum, $G$. citri-aurantii and A. citri. These results were in accordance with Yahyazadeh et al. [6], who reported that thyme and clove essential oils completely inhibited

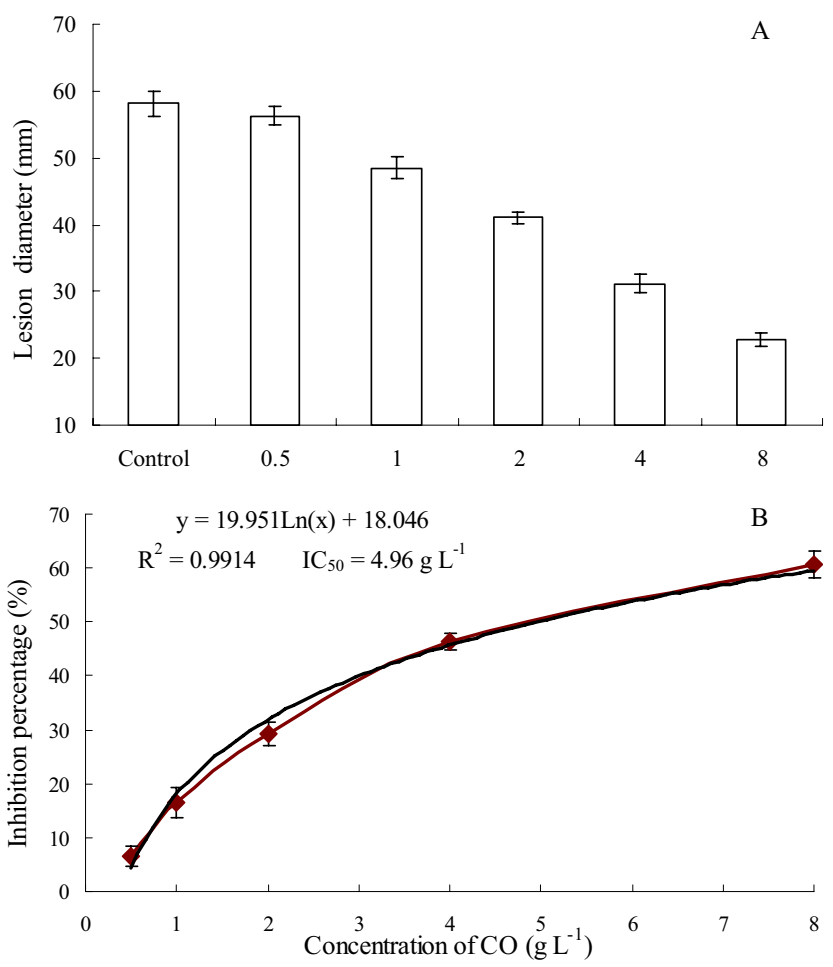

Figure 1. Effects of clove oil (CO) on (A) the lesion diameter (in $\mathrm{mm}$ ) and, (B) the inhibition percentage of citrus fruit after 7 days of incubation with Penicillium italicum at $25^{\circ} \mathrm{C}$.

$P$. digitatum growth in an in vitro mycelial growth assay when added to the medium at a rate of $600 \mu \mathrm{L} \mathrm{L}^{-1}$. Similarly, the efficacy of Mentha spicata and Lippia scaberrima essential oils in controlling citrus green mold caused by Penicillium digitatum was also reported by du Plooy et al. [27].

\subsection{In vivo antifungal activity}

The application of clove oil was effective for controlling blue mold of citrus fruit caused by Penicillium italicum (figure 1 and table $I I)$. As shown in figure 1 , when the lesion diameters of control citrus fruit reached $58.1 \mathrm{~mm}$ after incubation for 7 days at $25{ }^{\circ} \mathrm{C}$, the inhibition percentage was between $6.5 \%$ and $60.8 \%$ at concentrations of clove oil ranging from 0.5 to $8 \mathrm{~mL} \mathrm{~L}^{-1}$ (figure 2). The value of the $\mathrm{IC}_{50}$ obtained by statistical analysis was $4.96 \mathrm{~mL} \mathrm{~L}^{-1}$ (table II). 
Table II. Effect of clove oil (CO) against Penicillium italicum of citrus fruit under in vivo conditions. Colony diameter was recorded after 7 days of incubation at $25^{\circ} \mathrm{C}$. Data are means \pm standard errors $(n=5)$.

\begin{tabular}{lccc}
\hline $\begin{array}{l}\text { CO treatments } \\
\left(\mathrm{g} \mathrm{L}^{-1}\right)\end{array}$ & $\begin{array}{c}\text { Average diameters } \\
\text { of lesions }(\mathrm{mm})^{\mathrm{y}}\end{array}$ & $\begin{array}{c}\text { Inhibition over } \\
\text { control }(\%)^{\mathrm{y}}\end{array}$ & $\mathrm{IC}_{50}\left(\mathrm{~g} \mathrm{~L}^{-1}\right)$ \\
\hline 8.0 & $22.8 \pm 1.03^{\mathrm{f}}$ & $60.8 \pm 0.84^{\mathrm{a}}$ & \\
4.0 & $31.2 \pm 1.47^{\mathrm{e}}$ & $46.3 \pm 1.08^{\mathrm{b}}$ & \\
2.0 & $41.1 \pm 0.88^{\mathrm{d}}$ & $29.2 \pm 1.01^{\mathrm{c}}$ & 4.96 \\
1.0 & $48.5 \pm 1.58^{\mathrm{c}}$ & $16.5 \pm 0.76^{\mathrm{d}}$ & \\
0.5 & $54.3 \pm 1.33^{\mathrm{b}}$ & $6.5 \pm 0.93^{\mathrm{e}}$ & \\
0 (Control) & $58.1 \pm 1.79^{\mathrm{a}}$ & & \\
\hline
\end{tabular}

y The different lowercase letters within columns indicate significant differences according to Duncan's new multiple range test $(P<0.05)$.

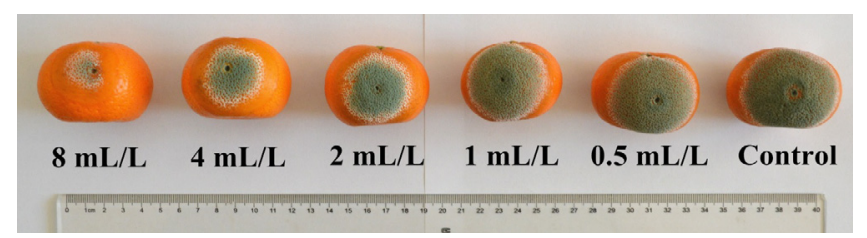

Figure 2. Control efficacy of clove oil at concentrations from 0.5 to $8.0 \mathrm{~mL} \mathrm{~L}^{-1}$ against blue mold caused by Penicillium italicum.

Many studies have documented the in vitro efficacy of essential oils against common postharvest diseases of citrus fruit $[6,28,29]$. To be considered as potential natural fungicides, high inhibition of disease development, a low additive dose, and a positive effect on fruit quality are necessary. In the present study, we conclude that the $\mathrm{IC}_{50}$ value of clove oil for controlling citrus blue mold was $4.96 \mathrm{~mL} \mathrm{~L}^{-1}$ (table II and figure 2). Similarly, Regnier et al. [30] documented that Lippia scaberrima essential oil had high fungistatic activity against Botryosphaeria parva and Colletotrichum gloeosporioides, and reduced fungal infection of mango fruit.

\subsection{Effect of CMC enriched with clove oil on the weight loss and decay rate}

Weight loss is one of the most critical quality attributes of the postharvest life and quality of fruit during storage. As can be inferred from figure $3 A$, the weight loss of all samples increased gradually in both coated and uncoated fruit throughout the cold storage $(P<0.05)$ due to the loss of water caused by evaporation, transpiration and respiration processes. It was found that both the CO-CMC- and CMC-coated fruits had less weight loss during storage than the control group (figure $3 \mathrm{~A}$, $P<0.05)$. At the end of storage, the control group clearly showed the highest weight loss $(6.83 \%)$, while the weight loss of the CO-CMC- and CMC-coated fruits reached $4.64 \%$ and $5.07 \%$, respectively. It is universally accepted that migration of water from fruit to the environment is the major cause of weight loss of fruit [17]. Our results were consistent with previous studies indicating that the use of menthol and thymol essential oils in sweet cherry led to a reduction in weight loss [18].
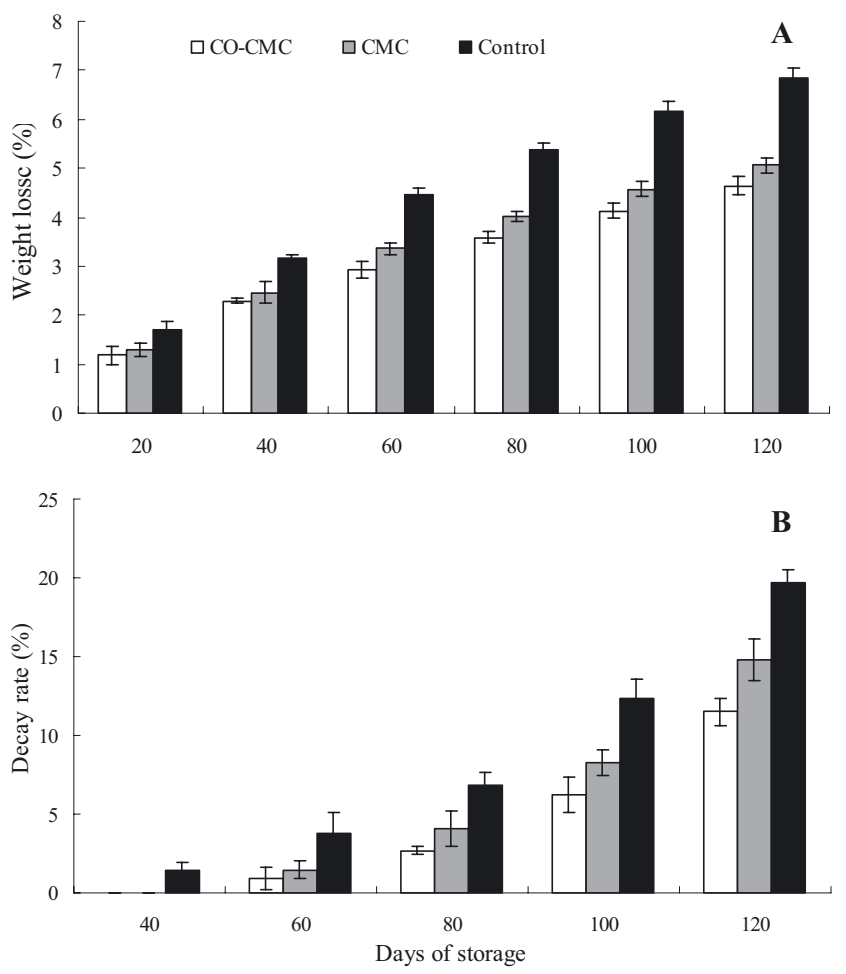

Figure 3. Changes in (A) weight loss (in \%) and (B) decay rate (in \%) of 'Xinyu' mandarin oranges stored at $5{ }^{\circ} \mathrm{C}$ for 120 days. Bars indicate standard deviation of three replicates (CO: clove oil, CO-CMC: clove oil-carboxymethyl cellulose).

The decay $\%$ is another major determining factor that affects the preservation effect of horticultural produce. There was no visible sign of decay in coated or control fruits up to 40 days of the storage period (figure $3 B$ ). Thereafter, the coatings significantly $(P<0.05)$ reduced decay compared with the control group. Many of the control fruits $(23.4 \%)$ were rotten at the termination of the storage, while fruits treated with $\mathrm{CO}$ CMC coating and CMC coating exhibited a significantly lower decay \% than the control group at the level of $P<0.05(13.7 \%$ and $16.8 \%$, respectively). Fruit decay in 'Xinyu' mandarin oranges is usually caused by fungi, with blue mold (Penicillium italicum) and sour rot (Geotrichum candidum) being identified as the two most common postharvest diseases.

\subsection{Effect of CMC enriched with clove oil on fruit quality}

The changes in the concentrations of soluble solids (TSS), acidity (TA) and vitamin C (VC) are shown in figure 4. The TSS concentration increased continuously during the early stage of storage and decreased slightly in the subsequent storage period. The TSS concentration in the control group reached $11.60 \pm 0.10{ }^{\circ}$ Brix after 20 days, while the coated groups reached their highest sugar level $(12.14 \pm 0.06$ and $11.9 \pm 0.10^{\circ}$ Brix, respectively), delaying the onset of disease 20 days longer than the control group, being stored for 40 days. There are significant differences among the three peaks. During the later storage stage, the TSS concentration of fruit 

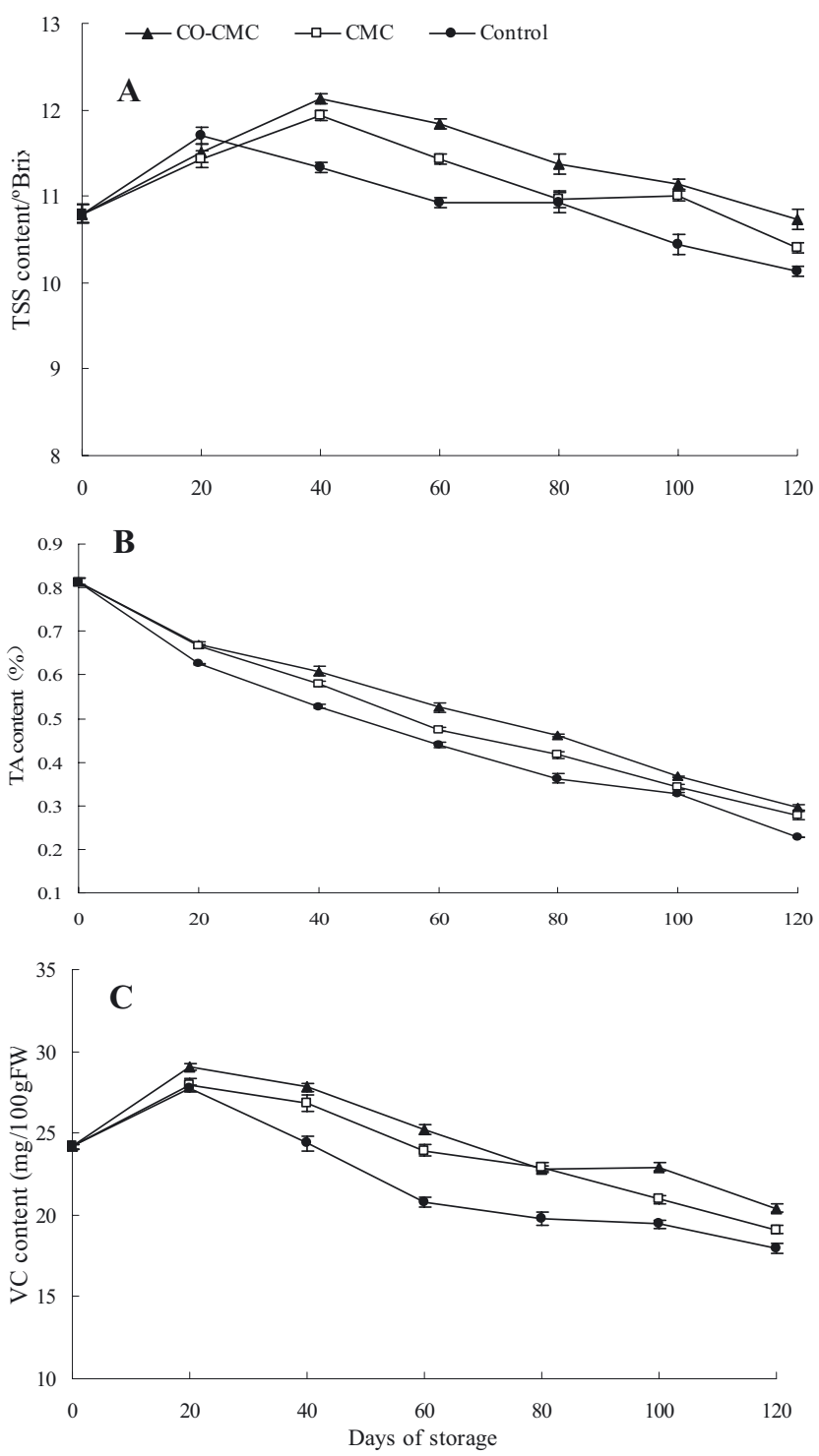

Figure 4. Changes in (A) total soluble solids (TSS, in ${ }^{\circ}$ Brix), (B) titratable acidity (TA, in \%), and (C) vitamin C content (VC, in mg $100 \mathrm{~g}$ fresh weight) of 'Xinyu' mandarin oranges stored at $5{ }^{\circ} \mathrm{C}$ for 120 days. The mean \pm standard error of three randomly selected replicates from ten fruits in each treatment, is indicated for each value (CO: clove oil, CO-CMC: clove oil-carboxymethyl cellulose).

treated with $\mathrm{CO}-\mathrm{CMC}$ coating was significantly higher $(P<$ $0.05)$ than the CMC-coated and control groups. The results showed that the coatings provided a beneficial semi-permeable film around the fruit, modifying the internal atmosphere by elevating $\mathrm{CO}_{2}$ and/or reducing $\mathrm{O}_{2}$ and delaying the degradation rate of nutrients in the fruit [19]. Meanwhile, the TSS content in CO-CMC-coated fruits was significantly higher $(P<0.05)$ than in the CMC-coated fruits during the late stage of storage, which points to the possible effect of CMC coating combined with clove oil on the metabolic activity of 'Xinyu' mandarin oranges. These results are in accordance with those observed by Perdones [20], who reported that the use of chitosan edible coating containing lemon essential oil on strawberry deferred
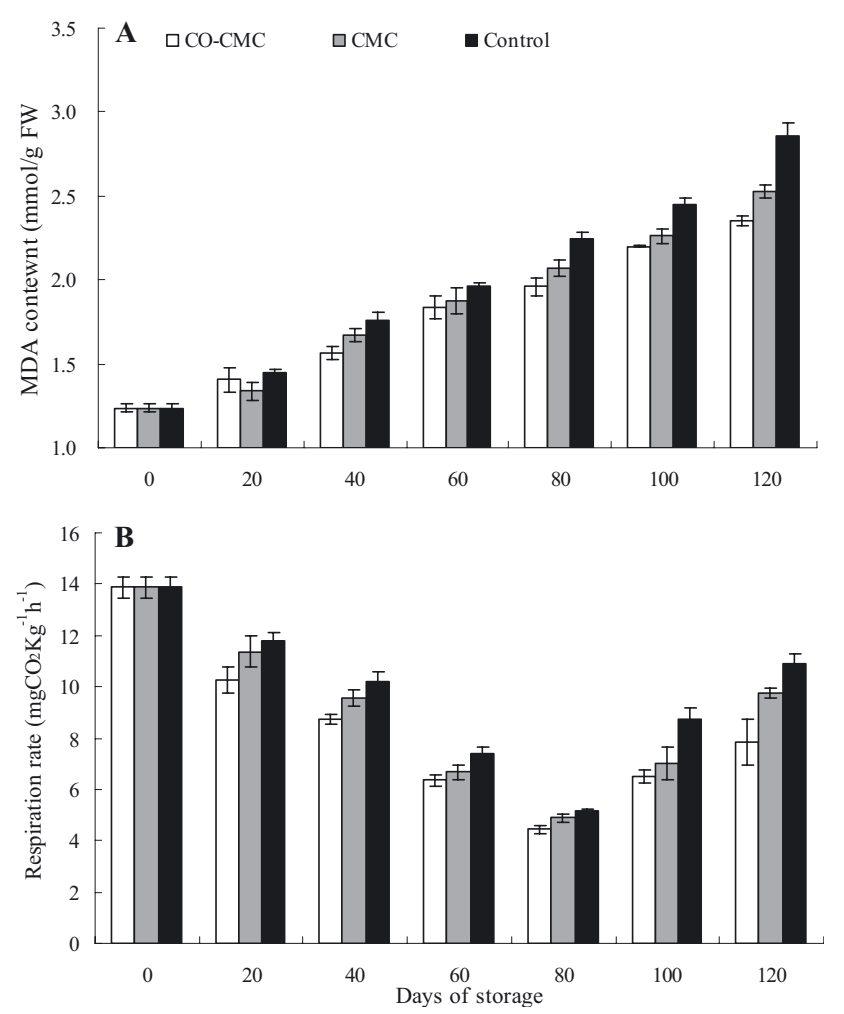

Figure 5. Changes in (A) MDA content (MDA, in mmol $\mathrm{g}^{-1}$ fresh weight), and (B) respiration rate (in $\mathrm{CO}_{2} \mathrm{~kg}^{-1} \mathrm{~h}^{-1}$ ) of 'Xinyu' mandarin oranges stored at $5{ }^{\circ} \mathrm{C}$ for 120 days. The mean \pm standard error of three randomly selected replicates from ten fruits in each treatment, is indicated for each value (CO: clove oil, CO-CMC: clove oilcarboxymethyl cellulose).

the degradation rate of nutrients during the middle and later periods of storage.

The TA concentration of all samples fell greatly after 120 days of storage (figure $2 B$ ) and the value was significantly higher $(P<0.05)$ in CO-CMC-coated fruit compared with the control group. Since organic acids in fresh fruit, such as citric or malic acid, are primary substrates for respiration, the high respiration rate leads to the reduction in acidity [21].

The vitamin $\mathrm{C}$ concentration (VC) of coated and control fruits increased to a maximum after 20 days of storage and declined in the subsequent storage period (figure $4 C$ ). The highest levels of the $\mathrm{VC}$ were observed in the $\mathrm{CO}-\mathrm{CMC}$-coated fruits, closely followed by fruit treated with $\mathrm{CMC}$ coating. During the later storage stage, the VC of CO-CMC-coated fruits was significantly higher $(P<0.05)$ than the control fruits. In citrus fruit, the VC increases with maturity and the stage of ripening; however, once fruits reach the stage of full ripening, the VC starts to decline [22].

\subsection{Effect of CMC enriched with clove oil on the MDA content and respiration rate}

Maleic dialdehyde (MDA) is the final product of lipid peroxidation, and its content has been used as one of the direct indices of cell oxidative damage [23]. As shown in figure 5A, the MDA content increased, and a significant difference was 

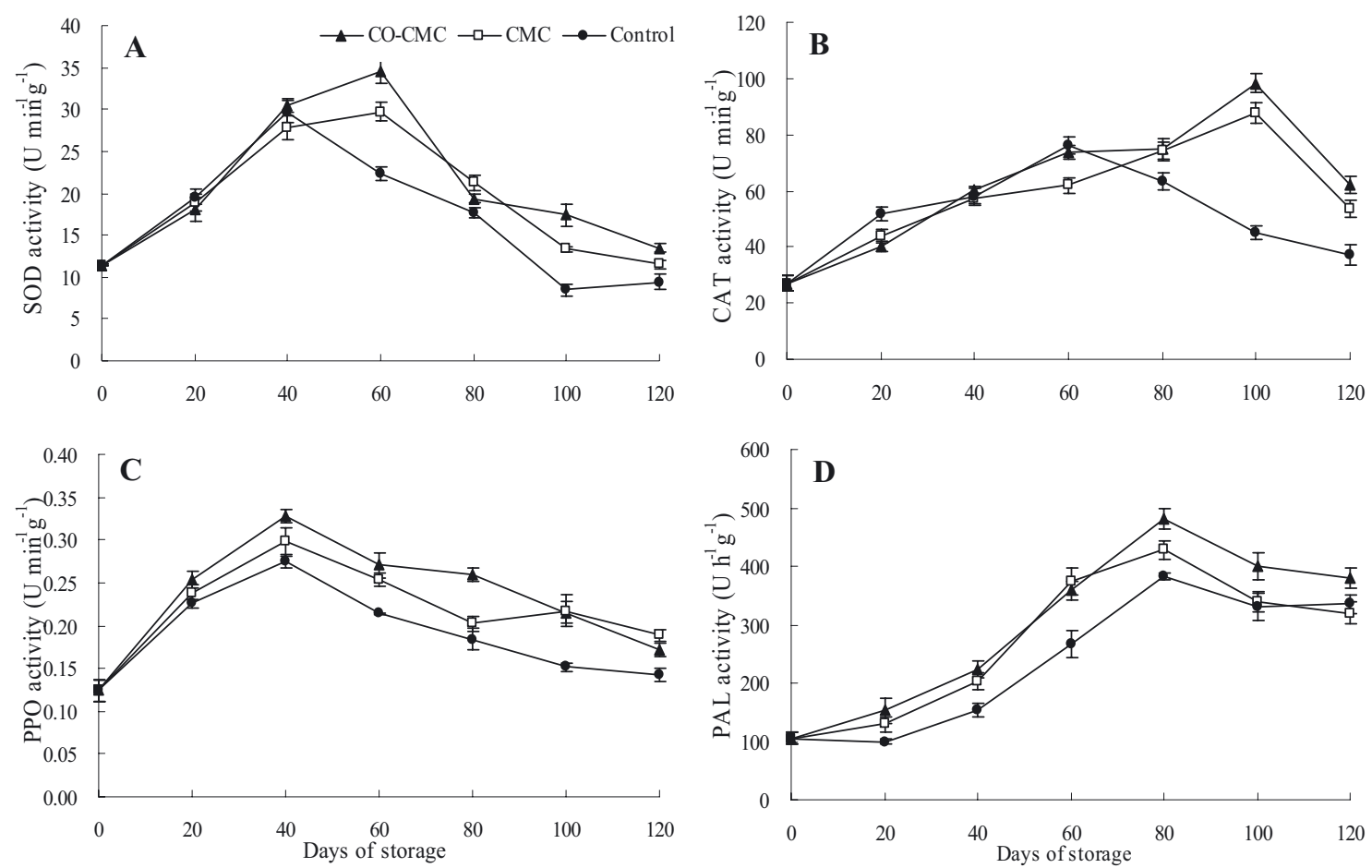

Figure 6. Changes in the (A) superoxide dismutase (SOD), (B) catalase (CAT), (C) polyphenol oxidase (PPO, all in $\mathrm{U}^{\mathrm{min}}{ }^{-1} \mathrm{~g}^{-1}$ ), and (D) phenylalanine ammonialyase (PAL in $\mathrm{U} \mathrm{h}^{-1} \mathrm{~g}^{-1}$ ) enzyme activities of peels of 'Xinyu' mandarin oranges stored at $5{ }^{\circ} \mathrm{C}$ for 120 days. The mean \pm standard error of three randomly selected replicates from ten fruits in each treatment, is indicated for each value.

shown between the coated and control groups. At the end of the storage period, the MDA concentration of the control reached a maximum $\left(2.85 \mathrm{mmol} \mathrm{g}^{-1}\right)$ which was $17.5 \%$ higher than the CO-CMC coating and $11.8 \%$ higher than the CMC coating.

The respiration rate decreased gradually and reached a minimum value, and then rose slightly in the subsequent storage period (figure 5B). A sudden decrease in the respiration rate was observed after storage for 80 days in all treatments, and the highest decrease was observed in the fruit treated with $\mathrm{CO}-\mathrm{CMC}$ coating. There are significant differences among the three minima $(4.43 \pm 0.16,4.88 \pm 0.13$, and $5.17 \pm 0.07 \mathrm{mg}$ $\mathrm{CO}_{2} \mathrm{~kg}^{-1} \mathrm{~h}^{-1}$ ). CO-CMC-coated fruits exhibited an obvious increase in the respiration rate during the entire storage period, and the respiration rate of the CO-CMC coating was significantly lower $(P<0.05)$ than that of the control group.

The respiration rate is an important indicator of metabolic activity and provides a pilot signal of the possible shelf life of horticultural products [31]. Meanwhile, fruit quality parameters, including TSS, TA and VC, reflect the storage properties of fruits and certain substrates of respiration. Fruit treated with CO-CMC coating was recorded with higher levels of TSS, TA and $\mathrm{VC}$, and lower levels of the respiration rate. These results showed that the coatings provided a beneficial semi-permeable film covering the fruit surface and retarded or restrained the respiration and transpiration in citrus fruit [32]. This finding is consistent with that reported by Azarakhsh et al. [33], when fresh-cut pineapple treated with the incorporation of lemongrass essential oil into an edible alginate-based coating caused minor carbon dioxide production and oxygen consumption, indicating delayed ripening and senescence as compared with the control.

\subsection{Effect of CMC enriched with clove oil on SOD and CAT activity}

To assess if the progress of senescence was associated with the induction of the antioxidant enzymes, SOD and CAT, reactive oxygen species (ROS)-metabolizing enzymes, have been proved to be important oxyradical detoxification enzymes in response to stress $[16,24,25]$. During cold storage at $5{ }^{\circ} \mathrm{C}$, the pattern of changes in SOD and CAT activities increased first, and then decreased gradually. The activities of SOD and CAT in the control group increased to reach the peak at 40 and 60 days after treatment, decreasing rapidly thereafter ( $f i g$ ures $6 A$ and $6 B$ ). The maximum enzyme activities of the coated fruits were delayed for 20 and 40 days, when compared with the control group. The peak of the CO-CMC-coated fruits was significantly higher than that of the control group. During the late stages of storage, the activities of SOD and CAT in the CO-CMC-coated fruits were significantly higher $(P<0.05)$ than in the CMC-coated and control fruits.

\subsection{Effect of CMC enriched with clove oil on PPO and PAL activity}

PPO and PAL have been confirmed to play crucial roles in plant tissues infected by pathogens. A steady increase for PPO and PAL activities was found in the first 40 and 80 days of storage in all treatments, and afterward the PPO and PAL activities decreased up to the end of the storage period. The fruits treated with $\mathrm{CO}-\mathrm{CMC}$ coating had significantly higher $(P<0.05)$ PPO activity compared with the control group, 
while PAL activity in the CO-CMC-coated fruits was significantly higher $(P<0.05)$ than in those of the other two groups (figures $6 C$ and $6 D$ ).

PPO has been confirmed to play a vitally important role in quinone synthesis, that is one of the first symptoms in response to fungal infection [34]. PAL is the key enzyme of the phenylpropanoid metabolism which is involved in the defense response of plant cells against pathogen invasion and enhancing disease resistance [16]. In the present study, we found that SOD, CAT, PPO and PAL in CO-CMC-coated fruits were higher than in the control group or fruits with CMC coating alone, for most of the fruit during the storage period. The reason was probably that clove oil added to CMC coating can induce activities of these enzymes, which play important roles in disease resistance in 'Xinyu' mandarin oranges [35]. Our results were in agreement with Zeng et al. [36], who found that carboxymethyl cellulose coating enriched with extract of Impatiens balsamina $\mathrm{L}$. stems could effectively enhance the activities of defense enzymes in navel orange.

\section{Conclusion}

The CO-CMC coating is potentially a natural and safe alternative treatment for enhancing fruit quality of 'Xinyu' mandarin oranges. The coated treatments significantly decreased the decay rate and weight loss, postponed fruit quality deterioration and enhanced the activities of SOD, CAT, PPO and PAL enzymes. The addition of clove oil as an antifungal fungicide to the CMC coating had an inhibitory effect on mold growth, when compared with the CMC coating alone. In addition, the CO-CMC coating had a significantly beneficial effect on the respiration rate, commercial quality and storage properties of 'Xinyu' mandarin oranges. This coating alleviated the degradation of TSS, TA and VC, when compared with the other treatments. Meanwhile, the results showed that the activities of $\mathrm{SOD}, \mathrm{CAT}, \mathrm{PPO}$ and PAL in fruits treated with the CO-CMC coating were higher than those in $\mathrm{CMC}$-coated and control samples. Therefore, our results indicated that the CO-CMC coating was considered beneficial for efficient application for 'Xinyu' mandarin orange postharvest preservation.

Acknowledgements. This research was supported by the National Science Foundation of China (31160343), National Science \& Technology Supporting Programs (2012BAD38B03) and Ministry of Agricultural Science \& Technology Achievements transformation fund of China (2011GB2C50017).

\section{References}

[1] Ao H.B., Ma S.Q., Zou Z.Q., Study on the Meteorological Conditions of Xinyu Tangerine Production, J. Anhui Agric. Sci. 43 (2015) 191-192.

[2] Chen C.Y., et al., Effects of chitosan coating on postharvest quality of Xinyu tangerine during ambient temperature storage, Acta Agric. Univ. Jiangxiensis. 34 (2012) 1112-1117.
[3] Chaieb K., Hajlaoui H., Zmantar T., Kahla-Nakbi A.B., Rouabhia M., Mahdouani K., Bakhrouf A., The chemical composition and biological activity of clove essential oil, Eugenia caryophyllata (Syzigium aromaticum L. Myrtaceae): a short review, Phytother. Res. 21 (2007) 501-506.

[4] Waterstrat P.R., Induction and recovery from anesthesia in channel catfish Ictalurus punctatus fingerlings exposed to clove oil, J. World Aquac. Soc. 30 (1999) 250-255.

[5] Xing Y., Xu Q.L., Li X.H., Che Z.M., Yun J., Antifungal activities of clove oil against Rhizopus nigricans, Aspergillus flavus and Penicillium citrinum in vitro and in wounded fruit test, J. Food Saf. 32 (2012) 84-93.

[6] Yahyazadeh M., Omidbaigi R., Zare R., Taheri H., Effect of some essential oils on mycelial growth of Penicillium digitatum Sacc., World J. Microb. Biotech. 24 (2008) 1445-1450.

[7] Cheng S.S., Liu J.Y., Chang E.H., Chang S.T. et al., Antifungal activity of cinnamaldehyde and eugenol congeners against wood-rot fungi, Bioresource Technol. 99 (2008) 5145-5149.

[8] Sanla-Ead N., Jangchud A., Chonhenchob V., Suppakul P., Antimicrobial activity of cinnamaldehyde and eugenol and their activity after incorporation into cellulose-based packaging films, Packag. Technol. Sci. 25 (2012) 7-17.

[9] Gol N.B., Patel P.R., Rao T.V.R., Improvement of quality and shelf-life of strawberries with edible coatings enriched with chitosan, Postharvest Biol. Technol. 85 (2013) 185-195.

[10] Wang Y., Tang F., Xia J.D., Yu T., Wang J., Azhati R., Zheng X.D., A combination of marine yeast and food additive enhances preventive effects on postharvest decay of jujubes (Zizyphus jujuba), Food Chem. 125 (2011) 835-840.

[11] Togrul H., Arslan N., Extending shelf-life of peach and pear by using CMC from sugar beet pulp cellulose as a hydrophilic polymer in emulsions, Food Hydrocolloids. 18 (2004) 215-226.

[12] Phongpaichit S., Subhadhirasakul S., Wattanapiromsakul C., Antifungal activities of extracts from Thai medicinal plants against opportunistic fungal pathogens associated with AIDS patients, Mycoses 48 (2005) 333-338.

[13] Xu S.X., Li Y.C., Liu X., Mao L.J., Zhang H., Zheng X.D., In vitro and in vivo antifungal activity of a water-dilutable cassia oil microemulsion against Geotrichum citri-aurantii, J. Sci. Food Agric. 92 (2012) 2668-2671.

[14] Hodges D.M., DeLong J.M., Forney C.F., Prange R.K., Improving the thiobarbituric acid-reactive-substances assay for estimating lipid peroxidation in plant tissues containing anthocyanin and other interfering compounds, Planta 207 (1999) 604-611.

[15] Havir E.A., McHale N.A., Biochemical and developmental characterization of multiple forms of catalase in tobacco leaves, Plant Physiol. 84 (1987) 450-455.

[16] Ballester A.R., Lafuente M.T., González-Candelas L., Spatial study of antioxidant enzymes, peroxidase and phenylalanine ammonia-lyase in the citrus fruit-Penicillium digitatum interaction, Postharvest Biol. Technol. 39 (2006) 115-124.

[17] Duan J., Wu R.Y., Strik B.C., Zhao Y.Y., Effect of edible coatings on the quality of fresh blueberries (Duke and Elliott) under commercial storage conditions, Postharvest Biol. Technol. 59 (2011) 71-79.

[18] Bal E., Effects of essential oil treatments combined with hot water treatment on improving postharvest life of sweet cherry, Fruits 67 (2012) 285-291.

[19] Lin D., Zhao Y., Innovations in the development and application of edible coatings for fresh and minimally processed fruits and vegetables, Compr. Rev. Food Sci. Food Saf. 6 (2007) 60-75. 
[20] Perdones A., Sánchez-González L., Chiralt A., Vargas M., Effect of chitosan-lemon essential oil coatings on storagekeeping quality of strawberry, Postharvest Biol. Technol. 70 (2012) 32-41.

[21] El-Anany A., Hassan G., Rehab Ali F., Effects of edible coatings on the shelf-life and quality of Anna apple (Malus domestica Borkh) during cold storage, J. Food Technol. 7 (2009) 5-11.

[22] AOAC W.H., Official methods of analysis of the Association of Official Analytical Chemists. Association of Official Analytical Chemists, Arlington, VA, USA (1990).

[23] Xu W.T., Peng X.L., Luo Y.B., Wang J.A., Guo X., Huang K.L., Physiological and biochemical responses of grapefruit seed extract dip on 'Redglobe' grape, LWT, Food Sci. Technol. 42 (2009) 471-476.

[24] Sala J.M., Lafuente M.A.T., Antioxidant enzymes activities and rindstaining in 'Navelina' oranges as affected by storage relative humidity and ethylene conditioning, Postharvest Biol. Technol. 31 (2004) 277-285.

[25] Mittler R., Oxidative stress, antioxidants and stress tolerance, Trends Plant Sci. 7 (2002) 405-410.

[26] Shoresh M., Harman G.E., Mastouri F., Induced systemic resistance and plant responses to fungal biocontrol agents, Annu. Rev. Phytopathol. 48 (2010) 21-43.

[27] Du Plooy W., Regnier T., Combrinck S., Essential oil amended coatings as alternatives to synthetic fungicides in citrus postharvest management, Postharvest Biol. Technol. 53 (2009) 117-122.

[28] Plaza P., Torres R., Usall J., Lamarca N., Vinas I., Evaluation of the potential of commercial post-harvest application of essential oils to control citrus decay, J. Hortic. Sci Biotech.. 79 (2004) 935-940.
[29] Tripathi P., Dubey N.K., Banerji R., Chansouria J.P.N., Evaluation of some essential oils as botanical fungitoxicants in management of post-harvest rotting of citrus fruits, World J. Microb. Biotech. 20 (2004) 317-321.

[30] Regnier T., Du Plooy W., Combrinck S., Botha B. Fungitoxicity of Lippia scaberrima essential oil and selected terpenoid components on two mango postharvest spoilage pathogens, Postharvest Biol. Technol. 48 (2008) 254-258.

[31] Win T.O., Srilaong V., Heyes J., Kyu K.L., Kanlayanarat S., Effects of different concentrations of 1-MCP on the yellowing of West Indian lime (Citrus aurantifolia, Swingle) fruit, Postharvest Biol. Technol. 42 (2006) 23-30.

[32] Valverde J.M., Valero D., Martínez-Romero D., Guillén F., Castillo S., Serrano M., Novel edible coating based on Aloe vera gel to maintain table grape quality and safety, J. Agric. Food Chem. 53 (2005) 7807-7813.

[33] Azarakhsh N., Osman A., Ghazali H.M., Tan C.P., Mohd Adzahan N., Lemongrass essential oil incorporated into alginate-based edible coating for shelf-life extension and quality retention of fresh-cut pineapple, Postharvest Biol. Technol. 88 (2014) 1-7.

[34] Yoruk R., Marshall M.R., Physicochemical properties and function of plant polyphenol oxidase: a review, J. Food Biochem. 27 (2003) 361-422.

[35] Zeng R., Zhang A.S., Chen J.Y., Fu Y.Q., Postharvest quality and physiological responses of clove bud extract dip on 'Newhall' navel orange, Sci. Hortic. 138 (2012) 253-258.

[36] Zeng R., Zhang A.S., Chen J.Y., Fu Y.Q., Impact of carboxymethyl cellulose coating enriched with extract of Impatiens balsamina stems on preservation of 'Newhall' navel orange, Sci. Hortic. 160 (2013) 44-48. 